\title{
Extraction and application of dyestuffs from the leaves of guinea corn and onion skin
}

\author{
Emmanuel OSABOHIEN \\ Department of Chemistry, Delta State University, P.M.B 1, Abraka, Nigeria. \\ E-mail: osabohieneemma@yahoo.com \\ Tel: +2348036761310
}

\begin{abstract}
This research work is aimed at assessing the dyeing and colouring potentials of ethanol extracts from the leaves of guinea corn and the skin of onion. It is intended to apply the purified dye extracts on textile, drink and food. The leaves of guinea corn (Sorghum bicolor) and the skin of onion (Allium cepa) were collected, chopped, dried and pulverized. The powdered samples were extracted using ethanol absolute as solvent. The guinea corn leaves yielded dark red colour while the onion skin gave brownish red colour. The crude dyestuffs were purified by recrystallization in carbon tetrachloride $\left(\mathrm{CCl}_{4}\right)$. The percentage yields, melting points, $\mathrm{pH}$ and $\mathrm{R}_{\mathrm{F}}$ values are $10.64 \%$ and $9.83 \%, 186{ }^{\circ} \mathrm{C}$ and $194{ }^{\circ} \mathrm{C}, 7.10$ and $5.96,0.84$ and 0.53 respectively. UV/visible absorptions and IR spectra of dye samples were recorded. The dye samples obtained were used to colour food (pap) and drink (illicit gin). The dye baths made from these dyestuffs were used to dye some cotton fabrics, unmordanted and mordanted scoured fabrics. The products got from these dyeings, showed varied colour shades and hues. Wash and light fastness properties were carried out on the dyed fabrics. Both dyed fabrics experienced improved wash and light fastness with mordanting.
\end{abstract}

(C) 2014 International Formulae Group. All rights reserved.

Keywords: Natural dyes, textile dyeing, wash and light fastness, food and drink colouring.

\section{INTRODUCTION}

Dyes are chemical materials used to impart colours to substrates such as cosmetics, foods, drugs, hairs, furs, textiles and polymers (McGraw-Hill, 1970; Giles, 1974; KirkOthmer, 1976). All dyes were basically natural, extracted from some plants and animals until the advent of synthetic dyes in the middle of $19^{\text {th }}$ century (Giles, 1994, Osabohien, 2002; Osabohien et al., 2013). The roots, stems, leaves, flowers and fruits of various plants supplied vegetable dyes. Certain mollusks found on the shores of the Mediterranean Sea supplied animal dye as the famous tryrian purple (Giles, 1974).

Despite the teething problems associated with the use of natural dyes such as poor yield, poor affinity for textile materials and may be pollution hazards, there is the need for sustainable processes which can be seen as the driving force for the development of new strategies to the return of natural dyes. Natural dyes can exhibit better biodegradability and generally have higher compatibility with the environment 
compared to synthetic dyes (Spanier and Karman, 1987; Gill 1993; Brian and Jeffrey, 1993; Paul et al., 2003; Guinot et al., 2006; Osabohien, 2009; Otutu et al., 2010).

Furthermore, there have been worldwide efforts to promote the cultivation of natural dye plants and their application for dyeing by some projects such as the Pris CA of Italy and INDINK in UK (Tsatsaromi and LiakopoulouKyriakides, 1995; Otutu et al., 2010). There is the re-evaluation of ecology as a major trend for influencing colour, and it is believed that naturally dyed fabrics can meet the current global greening movement (Eunjou and $\mathrm{Ju}-$ Yeon, 2008). Nigeria has abundant natural resources in terms of dye plants which stores dyes in parts such as the roots, barks, leaves, seeds, fruits and flowers. Most of these plants have both medicinal and dye potentials (Keay, 1989; Gill, 1992; Akpuaka et al., 1998; Osabohien, 2009).

Onion (Allium cepa) is a plant species belonging to the lily family. It is classified under the same family with garlic, leak, chimes, scallions and shallots. It is called arubara in Edo, Arubasa in Isoko, Utita in Urhobo, Alubasa in Housa and Alubosa in Yoruba languages. It is widespread all over Europe, North America, Northern Africa and Asia. There are over 600 species of Allium distributed all over the world. The plants can be used as ornamentals, vegetables, spices or as medicine. There are many different varieties of onion as red, yellow, white and green, each with its own unique flavour, from very strong to mildly sweet. Onion can be eaten raw, cooked, fried, dried or roasted. Onions and other alliums are rich in thiosulphonates, sulphides, sulphoxides, and other odoriferous sulphur compounds. The cysteine sulphoxides are responsible for onion flavour and produce the eye-irritating compounds that induce lacrinanation. The thiosulphonates exhibit antimicrobial properties (FAO, 1995). Onion extract is rich in a variety of sulphides which provide some protection against tumour growth and stomach cancer. It is rich also in fructo-oligosaccharides which stimulate growth of healthy bifidobacteria and suppress growth of potentially harmful bacteria in the colon. Onions are rich in flavonoids which can provide protection against cardiovascular disease although to lesser degree compared to garlic. Onions can improve lung function especially in asthmatics. The more pungent varieties of onion, the greater concentration of healthpromoting phytochemicals (FAO, 1995).

Guinea corn (Sorghum bicolor) belong to the grass family, Poaceae. The genus Sorghum is one of about 600 genera of Poaceae. The genus is in the sub family, Panicodeae and the tribe, Andropogoneae. It is called kopo-kopo-re-corn in Yoruba, milomaize in United States (U.S), dura in sudan, great millet and guinea corn in West Africa, kafir corn in South Africa, mtama in Eastern Africa, and jowar in India (FAO, 1995)

Sorghum is characterized by an inflorescence (head) and grain (fruit or edible seed) in the form of a panicle, spikelets borne in pairs and extensively branching roots. It is particularly more grown in warmer climates of the world. As grain, sorghum is used as food for people, livestock and poultry. It is the fifth most important cereal crop in the world, the sorghum grass family has hollow stems (culms) that are plugged at intervals (the nodes), with leaves arising at the nodes. The leaves generally are differentiated into a lower sheath hugging the stems for a distance and a blade (FAO, 1995). A waxy coating on the leaves and stems helps to retain water even in intense heat. Sorghum is a perennial crop which can be harvested many times during the year (FAO, 1995). Sorghum bicolor originated in Northern Africa and can grow in arid soils and can withstand 
prolonged droughts. It grows in clumps that may reach over four meters high. The grain (kernel or seed) is small, reaching about 3-4 $\mathrm{mm}$ in diameter. The colour of the spherical seeds varies from white through red and brown, pale yellow to deep purple brown (FAO, 1995).

The United States is the world's largest producer of sorghum followed by India and Nigeria (FSD, 2007). In the U.S, it is mainly used for animal feed while it is used as food for people in India. The top exporters are the U.S., Australia and Argentina. Its growth habit is similar to that of maize (corn), but with more side shoots and more extensively branched root system. It is generally used as food, fodder, the production of alcohol beverages, the production of biodiesel, construction of brooms and brushes and a host of other purposes.

This research work is based on assessing the dye and colouring potentials of the extracts from the dried skin of the onion (Allium cepa) and leaves of the guinea corn (Sorghum bicolor). The work is intended to utilize the extracts to dye textile (cotton) fabrics, colour local gin known commonly as ogogoro and pap also called akamu both in Nigeria.

\section{MATERIALS AND METHODS Materials}

The leaves of guinea corn (Sorghum bicolor) used for this work was obtained from Obiaruku market while the onion (Allium сера), cotton fabrics, local gin and pap were bought from Abraka market, all in Delta State, Nigeria. Industrial, analar grades and BDH chemicals and equipment used for this work were obtained from the Chemical Laboratory, Department of Chemistry, Delta State University, Abraka, Nigeria.

The UV/visible spectrophotometer used was obtained from Global Environmental Consultants, Warri, Delta State, Nigeria while the infra-red spectrophotomer was obtained from Nigerian Institute of Science Laboratory
Technology, Ibadan, Nigeria. The Gallen kemp melting point apparatus was used to determine melting points of the dye samples.

\section{Methods \\ Solvent extraction}

The leaves of guinea corn (Sorghum bicolor) and skins of onion (Allium cepa) were collected, chopped, dried and ground to fine powder to allow for most intimate contact with solvent (Stahl, 1965). Measured quantities of pulverized samples were fed into the soxhlet extractor and mixed with the absolute ethanol as solvent in a ratio of 1:50 of powdered plant sample to ethanol solvent. That is $1.0 \mathrm{~g}$ of powdered plant sample was extracted with $50 \mathrm{ml}$ ethanol. The mixture of solvent-sample was refluxed for $3 \mathrm{hrs}$. The extract phases generated through several operations of the extraction process were first distilled to recover parts of the solvent before evaporating to dryness to obtain dried solid dye samples. The crude extracts were recrystallized using carbon tetrachloride as solvent and finally air dried to obtain purified dye samples. The following characteristics; percentage yield, $\mathrm{pH}$ value, melting point, colour and solubility parameters were determined for the purified dye samples.

\section{Thin-layer chromatography (TLC)}

The eluting solvents in the TLC operation were Diethyl ether, glacial acetic acid and toluene in a ratio of $3: 4: 3$ respectively. The dye spots on the chromatoplate were eluted with solvent mixture in a covered beaker. This separated the dye extracts into different colour spots at different distances up the plate. The chromatograms were developed on a microscope slide (Vogel, 1978). The colour spots were scraped off the plate, dried and visually observed for identification of actual colours. 


\section{UV/Visible and Infra-red spectrophotometry}

The UV/visible spectra of the dye specimens were recorded with the Pye unicam 5625 UV/visible spectrophotometer. The absorption peaks $\left(\lambda_{\max }\right)$ at different absorbances were obtained using hexane as solvent to make the dye solutions. The infra-red spectra were determined by the use of the spectra BS instrument and recorded (Figures 1 and 2).

\section{Dyeing process of the textile fabrics Preparation of the dye baths and dyeing}

$1.0 \mathrm{~g}$ each of the dried dye samples were measured into two separate beakers and made into paste forms with little water. They were then washed into two separate clean $500 \mathrm{ml}$ flat-bottom flasks with water to make up to 100 $\mathrm{ml}$ dye solutions. The solutions were boiled for about $5 \mathrm{~min}$. to aid good dissolution of the dyes and then cooled. For a liquor ratio of $50: 1,2.0 \mathrm{~g}$ of scoured white cotton material was introduced into the dye bath and heated to about $70{ }^{\circ} \mathrm{C}$ and left for about $30 \mathrm{~min}$. to achieve optimum exhaustion of the dyebath. The materials (cotton) from each dye bath were removed and allowed to cool. They were then washed with cold water to remove loose dye particles adhering to the fabric surfaces. The cotton fabrics were then air-dried and tested for light and wash fastness properties.

In another operation, scoured white cotton fabrics were mordanted with $2 \%$ solutions of potassium dichromate, alum iron sulphate and stannous chloride respectively and warned for about $30 \mathrm{~min}$. at about $60{ }^{\circ} \mathrm{C}$. They were then dyed in a similar way in the dyebaths of the two different dyestuffs used. The mordanted and unmordanted fabrics were compared in terms of colour shades, hues and fastness properties.

\section{Fastness properties of dyed fabrics Light Fastness}

Two sets of the dyed cotton fabrics were prepared. One set was exposed to sunlight for a period of about a week, while the second set was kept in the dark wrapped in black polythene bags. The exposed ones were rated to the unexposed fabrics on a grey scale (Trotman, 1970; Nkeonye, 1987; Osabohien and Ukponmwan, 2002; Osabohien, 2009). This was done in the absence of the American Association of Textile Chemists and Colourists (AATCC) standards.

\section{Wash Fastness}

Here, also two sets of the dyed cotton fabrics were prepared. One set was treated with soap solutions at room temperature for 30 min. in a Lini test wash wheel machine in accordance with ISO washing test No. 3. The treated fabrics were compared with the untreated fabrics in a grey scale (Nkeonye, 1987; Akpuaka et al., 1998; Otutu et al., 2010).

\section{Food (pap) colouring}

$10.0 \mathrm{~g}$ of pap (akamu) was first dissolved in water to make the pap solution. Then $1.0 \mathrm{~g}$ of dry dye sample was measured into a glass beaker, water was added gradually with stirring to make about $100 \mathrm{ml}$ dye solution and then heated to boil. The boiling dye solution was poured into the pap solution in a cooking stainless pot and stirred vigorously until a uniform semi-solid pap meal was obtained.

\section{Alcoholic drink (illicit gin) colouring}

$1.0 \mathrm{~g}$ of the dry dye sample was mixed with $100 \mathrm{ml}$ of illicit gin commonly called ogogoro in a glass bottle. The bottle was corked and shaken vigorously for about 10 min. A homogenous mixture was formed with fine colour shades respectively for the two different dye samples under test.

\section{RESULTS}

The results of the foregoing analyses and tests are presented in Tables $1-5$ and 
Figures 1 and 2. Table 1 depicts some physical properties of the dye extracts from onion skin and guinea corn leaf. The percentage yield, $\mathrm{pH}$, melting point, colour and solubility parameters are presented. Table 2 presents the retention factor $\left(R_{f}\right)$ of the dye extracts obtained from thin-layer chromatography.

Table 3 presents the UV/Visible spectral data, the absorption peaks $\left(\lambda_{\max }\right)$ and absorbances of the dye extracts are shown.
Table 4 reports the colour shades or hues and fastness properties of the dyes on a cotton fabric. The light and wash fastness ratings of the dyed fabrics are presented. The colours imparted on substrates, food (pap) and drink (illicit gin) are shown in Table 5. Figures 1 and 2 show the IR spectra of the dye extracts. The spectra regions of the absorptions are typified in the figures.

Table 1: Physical properties of dye extracts.

\begin{tabular}{|c|c|c|c|c|c|c|}
\hline \multirow[t]{2}{*}{ Dye plant } & \multirow[t]{2}{*}{ Yield (\%) } & \multirow[t]{2}{*}{ pH value } & \multirow{2}{*}{$\begin{array}{c}\text { M.pt } \\
\left({ }^{\circ} \mathbf{C}\right)\end{array}$} & \multirow{2}{*}{$\begin{array}{c}\text { Colour of } \\
\text { aqueous solution }\end{array}$} & \multicolumn{2}{|c|}{ Solubility } \\
\hline & & & & & Cold water & Hot water \\
\hline $\begin{array}{l}\text { Onion } \\
\text { Skin }\end{array}$ & 9.83 & 5.96 & 194 & $\begin{array}{l}\text { Brownish } \\
\text { red }\end{array}$ & $\begin{array}{l}\text { Sparingly } \\
\text { soluble }\end{array}$ & $\begin{array}{l}\text { Readily } \\
\text { soluble }\end{array}$ \\
\hline $\begin{array}{l}\text { Guinea } \\
\text { corn leaf }\end{array}$ & 10.64 & 7.10 & 186 & Reddish brown & $\begin{array}{l}\text { Sparingly } \\
\text { soluble }\end{array}$ & $\begin{array}{l}\text { Readily } \\
\text { soluble }\end{array}$ \\
\hline
\end{tabular}

Table 2: Evaluation of Chromatograms.

\begin{tabular}{lccc}
\hline Dye extract & $\begin{array}{c}\text { Distance moved by solvent } \\
\text { front }(\mathbf{c m})\end{array}$ & $\begin{array}{c}\text { Distance moved by } \\
\text { solute }(\mathbf{c m})\end{array}$ & $\mathbf{R}_{\mathbf{f}}$ value \\
\hline Onion skin & 6.8 & 3.6 & 0.53 \\
Guinea corn leaf & 6.3 & 5.3 & 0.84 \\
\hline
\end{tabular}

Table 3: UV/visible spectral analysis.

\begin{tabular}{lccl}
\hline Dye extract & Absorbances & $\boldsymbol{\lambda}_{\max }(\mathbf{n m})$ & Structure assignment \\
\hline \multirow{3}{*}{ Onion skin } & 2.577 & 650 & Quinone type \\
& 2.165 & 750 & Structure suspected, \\
& 1.757 & 850 & Chromophoric systems present \\
\hline \multirow{3}{*}{ Guinea Corn leaf } & 1.536 & 950 & Quinone type \\
& 2.828 & 850 & Structure suspected, \\
& 2.953 & 950 & Chromophoric groups present \\
\hline
\end{tabular}


Table 4: Colour shades/hues and fastness properties of dyes.

\begin{tabular}{llcc}
\hline $\begin{array}{l}\text { Dye extract and } \\
\text { mordants }\end{array}$ & Fabric colour (cotton) & $\begin{array}{c}\text { Light fastness } \\
\text { (Gray scale) }\end{array}$ & $\begin{array}{c}\text { Wash fastness } \\
\text { (White soap) }\end{array}$ \\
\hline Onion skin & Reddish pink & $2-3$ & $2-3$ \\
Unmordanted & Yellowish brown & $4-5$ & $4-5$ \\
$\mathrm{~K}_{2} \mathrm{Cr}_{2} \mathrm{O}_{7}$ mordant & Light yellow & $3-4$ & $3-4$ \\
$\mathrm{Sncl}_{2}$ mordant & Light yellow & $3-4$ & $3-4$ \\
$\mathrm{FeSO}_{4}$ mordant & Yellow & $3-4$ & $3-4$ \\
Alum mordant & & $2-3$ & $2-3$ \\
Guinea corn leaf & Reddish brown & $4-5$ & $4-5$ \\
Unmordanted & Brownish yellow & $3-4$ & $3-4$ \\
$\mathrm{~K}_{2} \mathrm{Cr}_{2} \mathrm{O}_{7}$ mordant & Light brown & $3-4$ & $3-4$ \\
$\mathrm{SnCl}_{2}$ mordant & Deep brown & $3-4$ & $3-4$ \\
$\mathrm{Feso}_{4}$ mordant & Brown & & \\
$\mathrm{Alum}^{\text {mumordant }}$ & & &
\end{tabular}

1-2 most colour change; 2-3 colour change; 3-4 slight colour change; 4-5 colour retained

Table 5: Colour imparted on substrates.

\begin{tabular}{lcc}
\hline Dye extract & Substrate & Colour imparted \\
\hline Onion skin & Pap (akamu) & Light brown \\
& Illicit gin (ogogoro) & Reddish brown \\
\hline Guinea corn leaf & Pap (akamu) & Brownish-red \\
& Illicit gin (ogogoro) & Dark Red \\
\hline
\end{tabular}

\section{DISCUSSION}

The dye samples derived from the onion skin and guinea corn Leaves were found to be readily soluble in hot water and organic solvents. The yields were however poor (Table 1) which is characteristic of natural dyes (Osabohien and Ukponmwan, 2002; Osabohien, 2009). The results indicated acidic dye from onion skin and neutral dye for the sample got from guinea corn leaf with $\mathrm{pH}$ values of 5.96 and 7.10 respectively (Table 1). The onion skin produced a brownish red colour with melting point of $194{ }^{\circ} \mathrm{C}$ while the guinea corn leaf gave a reddish brown colour with melting point of $186{ }^{\circ} \mathrm{C}$. The chromatograms of the dye samples from the onion skin and guinea corn leaf were evaluated which gave $R_{\mathrm{f}}$ values of 0.53 and 0.84 respectively (Table 2 ). The absorption peaks obtained from the UV/visible spectral analysis showed evidence of colour bearing compounds (Osabohien and Otutu, 2009). From Table 3, the absorptions of the dye samples at $\lambda_{\max }$. $650-750 \mathrm{~nm}$ are consistent with reddish colours of the dyes (Webprojects, 2002). In Figure 1, the IR absorptions of the dye show the presence of chromophores and anxochromes such as $-\mathrm{OH}, \mathrm{N}-\mathrm{H}$ in the spectra regions of $3900-3200 \mathrm{~cm}^{-1}$ strong to medium bands. These may be due to presence of alcohols, phenols, amines and amides. - $\mathrm{C}-\mathrm{H}$ stretch exists in the region of $2974.39 \mathrm{~cm}^{-1}$, which may be due to the presence of alkanes. 


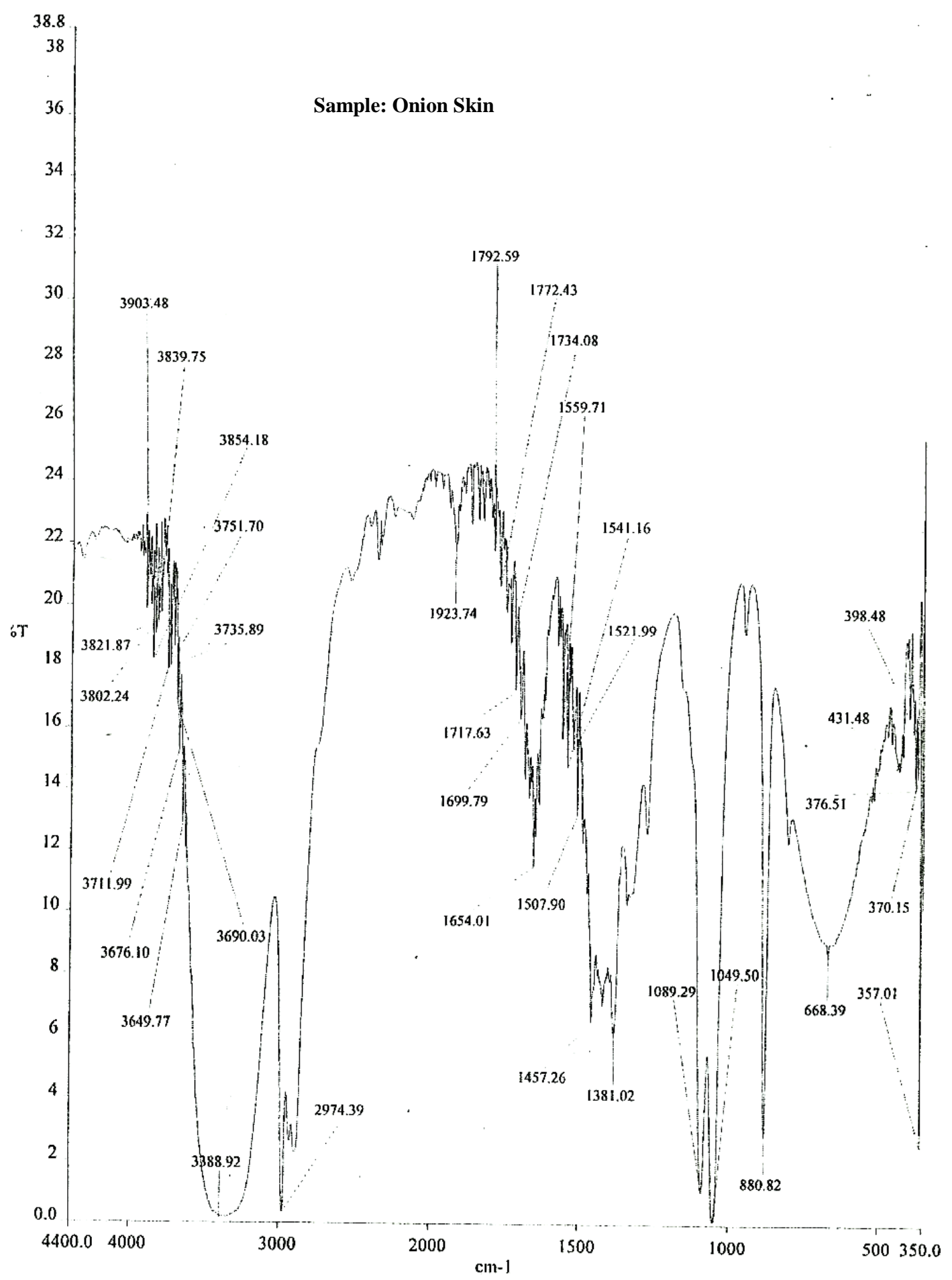

Figure 1: 1R Spectra of the dye extract from onion skins. 


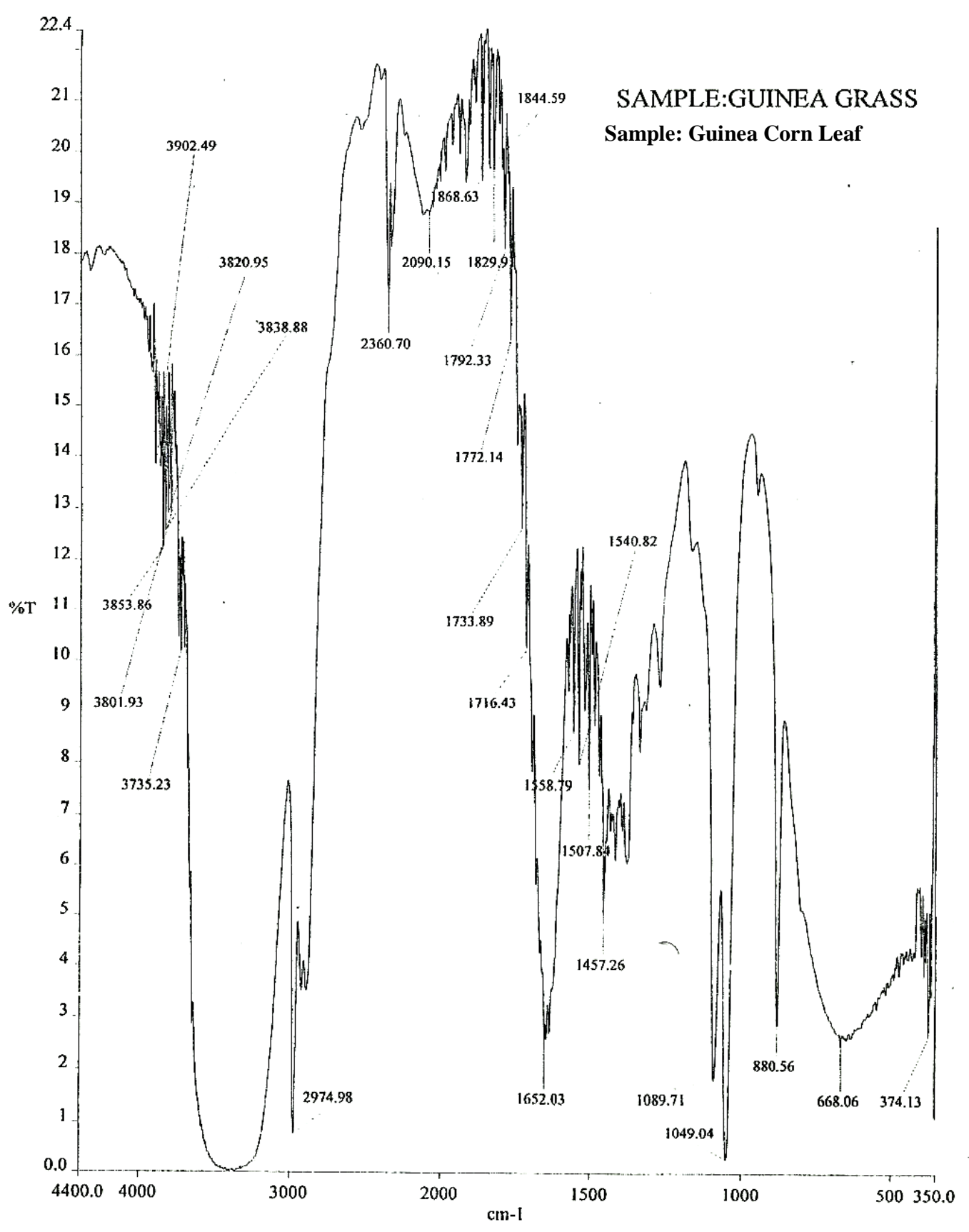

Figure 2: 1R Spectra of the dye extract from guinea corn leaf. 
Also there is a $\mathrm{C}-\mathrm{H}$ stretch in plane band in the region of $1457.26 \mathrm{~cm}^{-1}$ band associated with band alkanes.

Absorptions also exist in the regions of $1760-1690 \mathrm{~cm}^{-1}$ for the $\mathrm{C}=\mathrm{O}$ group which may be due to the presence of carboxylic acids. The absorptions at $1089.29-1049.50 \mathrm{~cm}^{-1}$ and $880.56 \mathrm{~cm}^{-1}$ may indicate the presence of sulphur related compounds and C-O group of alcohols and esters (Osabohien, 2009). In Figure 2, the same groups as in Figure 1 were present such as the $\mathrm{OH}, \mathrm{C}-\mathrm{H}_{\mathrm{str}}, \mathrm{C}-\mathrm{H}_{\text {str }}$ in plane bend, $\mathrm{C}-\mathrm{O}$ and $\mathrm{S}$. In addition, there exists the C-O-C bond type at $1652.03 \mathrm{~cm}^{-1}$ indicating the presence of ethers. There exist a broad band between 700-500 $\mathrm{cm}^{-1}$, though more conspicuous in Figure 2. This may suggest the presence of benzene ring structure in both dye samples. The absorption spectra did show the presence of impurities which may have arisen from incomplete removal of impurities through the recrystallization processes.

In Table 4, the dyed cotton fabrics showed varied colour shades and hues with different mordants, $\mathrm{K}_{2} \mathrm{Cr}_{2} \mathrm{O}_{7}, \mathrm{SnCl}_{2}, \mathrm{FeSO}_{4}$ and alum. The mordanted fabrics showed better light and wash fastness properties compared to the unmordanted fabrics. The chrome mordant gave best results (Table 4). The poor light and wash fastness of the unmordanted fabrics are characteristics of natural dyes compared to synthetic dyes (Akpuaka et al., 1998; Osabohien and Ukponmwan, 2002; Otutu et al., 2007; Osabohien, 2009; Otutu et al., 2010).

Table 5 shows the different colour hues imparted on food such as pap (akamu) and illicit gin (ogogoro). The colours improved the facial values of these food and drink. The harmless nature of most of these natural dyestuffs could allow for these applications since their sources have food values (Gill, 1993; FAO, 1995; Osabohien et al., 2013).

\section{Conclusion}

This work has achieved some level of success in the use of locally sourced materials for dye applications in textiles, food and drink colouring. However, the use of mordants in textile dyeings was found to be essential in improving colour shades and fastness properties of the dyes. Both plants, the onions and guinea corn have been found to be useful as food for man and also medicinal particularly the onion fruit. It is in this light that these plant dyestuffs are recommended for textile dyeing and colouration of foods, drinks and even cosmetics for the consumption of man. The use of these locally available raw materials that are renewable for our textile, food and cosmetics industries would enhance their value and increase national resource development and grass domestic products.

\section{REFERENCES}

Akpuaka MU, Chuwuneke C, Agho G. 1998. The Dyeing of textile fabrics with natural dyes from some local trees. $J$. Chem. Soc. Nigeria, 23: 47-52.

Brian G, Jeffrey HP. 1993. Dyeing with vegetable dyes. J. Soc. Dyers Colourists, 109: 5-7.

FAO 1995. Food and Agriculture Organization of United nations, Sorghum and millets in human nutrition, Chap 1 and 5, FAO Corporate Document Repository. Retrieved September, 5, 2013.

FSD 2007. Food Security Department. Sorghum, post-harvest operations Compendium. Retrieved September 5, 2013.

Giles GH. 1974. A Laboratory Course in Dyeing ( $3^{\text {rd }}$ edn). The Society of Dyers and Colourists: Bradford.

Gill D. 1993. The Return of Natural dyes. J. Soc. Dyers and Colourists, 109: 32. 
Gill LS. 1992. Ethnomedical Uses of Plants in Nigeria. University of Benin Press: Benin-City, Nigeria.

Guinot P, Roge A, Gargadennec A, Andry C. 2006. Dye plants screening: An approach to combine past heritage and present development. Coloration Technol., 122: 93-101.

Keay RWJ. 1989. Trees of Nigeria. Clarendon Press: Oxford, New York.

Kirk-Othmer. 1976. Encyclopaedia of Chemical Technology. John Wiley and Sons: USA.

McGraw-Hill 1970. Encyclopaedia of Science and Technology ( $6^{\text {th }}$ edn). McGraw-Hill Books Co.: New York.

Nkeonye PO. 1987. Fundamental Principles of Textile Dyeing, Printing and Finishing. Ahmadu Bello University Press: Zaria, Nigeria.

Osabohien E. 2009. Extraction and utilization of natural dyestuffs from Maesobotyra staudtii and Chrosophyllum albidum. Nig. J. Sci. Environ., 8: 93-97.

Osabohien E, Ukponmwan DO. 2002. Extraction of natural dyes from some local plants. J. Chem. Soc. Nigeria, 27(2): 139-142.

Osabohien E, Otutu JO, Ukponmwan DO. 2013. Dyeing and colouring using the extract from a plant; Bosqueia angolensis, Inter. Jour. Scientific Res., 3(1): 1-6.

Otutu JO, Osabohien E, Efurhievwe EM. 2010. Extraction of natural dyes for textile dyeing from the by-products of the timber industry. Biosci. Biotechnol. Res. Asia, 7(1): 87-92.

Paul S, Glover E, Sharma A. 2003. Ecofriendly dyeing of wool with Jatropha dye. Int. Dyer, 188: 55-60.

Spanier E, Karman N. 1987. The Royal Purple and Biblical Blue. Argaman and Tekhelet Editions: Jerusalem Keter.

Stahl E. 1965. Thin-layer Chromatography. A Laboratory Handbook. Academy Press: London.

Trotman ER. 1970. Dyeing and Chemical Technology of Textile Fibres $\left(4^{\text {th }}\right.$ edn). Charles Griffin: London.

Tsatsaromi E, Liakopoulou-Kyriakides M. 1995. Effects of enzymatic treatment on the dyeing of cotton and wool fibres with natural dyes. Dyes and Pigments, 29(3): 203-209.

Vogel AI. 1978. Textbook of Quantitative Inorganic Analysis ( $4^{\text {th }}$ edn). Longman: London.

Webprojects. 2002. Chemistry of Dyes: Basis of colour. www.chm.bris.webproject, 2002price/ colour.htm. Retrieved September 5, 2013. 